\title{
HUBUNGAN POLA MAKAN ANAK TERHADAP TINGKAT KEJADIAN EARLY CHILDHOOD CARIES (ECC) DI KELURAHAN TANAH GARAM KOTA SOLOK
}

Lala Viodita ${ }^{1}$, Rizanda Machmud ${ }^{2}$ Hidayati $^{3}$

Korespondensi :lalaviodita@yahoo.com Telp:082284224836

\begin{abstract}
Dental caries is the most commonly found for oral and dental diseases. It could appear in permanent and even desidual teeth. One of the oral and dental diseases prevalent to children of age 1-5 years old is termed Early Childhood Caries (ECC) which was an acute dental infection that rapidly develop from one third of primary servical maxillary incisivus into the whole teeth making white to yellowish cavity with soft caries tissue. Diet pattern gives big influence on incidence of caries. to find the relationship between children diet pattern with the case of ECC. observational analytical using cross- sectional design. Sample size was 50 children of age 2-3 years old in three different Comprehensive Treatment Post (CTP) in working area of Tanah Garam primary healthcare in Solok City. ECC prevalence in Tanah Garam District of Solok City in 2018 was $56 \%$. Diet pattern found mostly was cariogenic for $52 \%$. There was significant relationship between diet pattern with the case of ECC in Tanah Garam District of Solok City with $p=0.01$. There was significant relationship between diet pattern with the case of ECC in Tanah Garam District Solok City.
\end{abstract}

Keywords: Early Childhood Caries, Meal pattern

Affiliasi penulis : 1. Mahasiswa fakultas kedokteran gigi universitas adalas. 2. Departemen ilmu kesehaan masyarakat fakultas kedokteran universitas andalas. 3. Departemen ilmu kesehatan gigi masyarakat fakultas kedokteran gigi universitas andalas

\section{PENDAHULUAN}

Penyakit gigi dan mulut yang banyak ditemukan pada masyarakat adalah karies gigi. Karies gigi merupakan penyakit pada jaringan keras gigi yaitu enamel, dentin, dan sementum yang disebabkan oleh aktivitas suatu jasad renik dalam karbohidrat yang dapat difermentasikan. Proses yang ditandai dengan demineralisasi pada jaringan keras gigi yang kemudian diikuti oleh kerusakan zat organiknya, sehingga dapat terjadi invasi bakteri lebih jauh ke dalam gigi, yaitu ke jaringan periapeks. Karies gigi disebabkan oleh faktor host, mikroorganisme, substrat dan waktu. ${ }^{1,2,3,4}$

Karies tidak hanya ditemukan pada gigi permanen saja, tetapi juga bisa ditemukan pada gigi desidui. Salah satu gangguan kesehatan gigi dan mulut yang sering terjadi pada anak usia 1-5 tahun dikenal dengan istilah Early Childhood Caries (ECC). ECC merupakan penyakit infeksi pada gigi yang bersifat akut, dan berkembang dengan cepat yang awalnya terjadi pada sepertiga servikal gigi insisivus maksila sulung dan pada akhirnya akan merusak gigi secara keseluruhan, kavitas karies berwarna putih sampai kekuningan, jaringan karies lunak. Kondisi ini juga dikenal 


\section{ANDALAS DENTAL JOURNAL}

\section{Fakultas Kedokteran Gigi Universitas Andalas}

Jalan Perintis Kemerdekaan No. 77 Padang, Sumatera Barat

Web: adj.fkg.unand.ac.id Email: adj@ent.unand.ac.id

dengan nama berbeda, seperti : karies labial, karies incisor, nursing bottle mouth, rampan karies, nursing bottle caries, nursing caries, baby bottle tooth decay, rampant infant, dan early childhood dental decay ${ }^{5,6,7}$

Penderita ECC memiliki riwayat konsumsi gula dalam bentuk cairan dengan waktu lama dan sering. Gula penyebab karies seperti sukrosa, glukosa dan fruktosa yang terkandung dalam madu dan jus buah serta beberapa makanan formula bayi yang mudah diolah oleh Streptococcus mutans dan lactobacilli menjadi asam organik yang mengakibatkan demineralisasi email dan dentin. ECC juga dipengaruhi oleh cara pemberian minuman. Pada anak yang diberikan susu botol akan beresiko tinggi terjadinya ECC, karena produk susu mengandung karbohidrat yang merupakan media yang baik bagi kuman pembentuk asam. Keadaan ini akan mempermudah terbentuknya plak yang merupakan penyebab kerusakan gigi yang khas., ${ }^{8,9}$

Prevalensi kasus karies tertinggi pada anak-anak menurut WHO terdapat di Amerika dan kawasan Eropa, sementara prevalensi terendah adalah Asia tenggara dan Afrika. Riset Kesehatan Dasar ( Riskesdas ) Kemenkes RI tahun 2013 menunjukan 10,4\% anak berumur 1-4 tahun mengalami masalah dengan kesehatan gigi dan mulut di Indonesia. Penduduk Provinsi Sumatera Barat mempunyai masalah dengan kesehatan gigi dan mulut pada usia 1-4 tahun sebesar 5,4\% dan pada usia 5-9 tahun 23,5\% terlihat bahwa masalah kesehatan gigi dan mulut meningkat dengan pertambahan usia.

Anak yang mempunyai karies pada gigi sulung mempunyai kecenderungan tiga kali lebih besar untuk terjadinya karies pada gigi permanen. Presepsi masyarakat yang masih beranggapan perawatan gigi yang mahal dan gigi susu yang nantinya akan tanggal sendiri, membuat masyarakat menjadi kurang peduli dengan karies gigi sulung Hal ini dibuktikan dengan tidak tersedianya data mengenai kejadian karies dan karies gigi sulung pada anak usia kurang dari 6 tahun di Dinas Kesehatan Kota Solok. ${ }^{10,11}$

Deteksi dini ECC dapat mencegah masalah pada anak yaitu mempengaruhi kualitas hidup anak yang nantinya akan merugikan mereka. Pencegahan ECC dapat dilakukan dengan cara mengurangi faktor resikonya, salah satunya dengan mengubah pola makan anak. Masyarakat yang banyak mengkonsumsi makanan yang berserat cenderung mengurangi terjadinya karies daripada masyarakat yang mengkomsumsi makanan yang lunak dan banyak mengandung gula. Pada masa anak usia 1-3 tahun, dikelompokan sebagai konsumen pasif, di mana makanan yang dikonsumsi tergantung dari yang disajikan ibu. Konsep dasar pembahasan pola makan meliputi frekuensi makan, jenis dan bentuk makanan, serta cara konsumsi. Tingkat faktor resiko pengalaman karies seseorang dapat diketahui dengan cara menganalisa pola makan. Salah satu cara untuk 
menganalisa pola makan dikenal dengan Food Frequence Questionaire (FFQ) yang merupakan kuesioner untuk mengetahui frekuensi rata-rata dalam waktu yang ditentukan. Hasil penelitian Worotitjan Indry dkk menyatakan bahwa frekuensi mengonsumsi makanan dan minuman kariogenik mempengaruhi kejadian karies ${ }^{12,13,14,15}$.

Dalam data RISKESDAS Sumatera Barat tahun 2013, Kota Solok termasuk 12 terbesar yang bermasalah dalam kesehatan gigi \& mulut diwilayah Sumatera Barat dari 19 Kota / Kabupaten yang ada, yaitu sebesar 22,9\%. Menurut Info Publik Solok (IPS) menyatakan bahwa Posyandu Kota Solok termasuk Posyandu yang aktif dengan terbuktinya meraih penghargaan tingkat nasional yaitu penghargaan Pakarti Madya III pada tahun 2017. Wilayah Kota Solok dengan jumlah penduduk terbanyak terdapat di Kelurahan Tanah Garam.

Berdasarkan uaraian-uraian diatas peneliti tertarik untuk meneliti suatu permasalahan yaitu hubungan pola makan anak terhadap kejadian Early Childhood Caries di Kelurahan Tanah Garam Kota Solok. Pola makan anak dapat dinilai dengan Food Frequence Questionaire (FFQ) ( Worotitjan dkk, 2013) dan penilaian Early Childhood Caries dilakukan secara observasional.

\section{METODE}

Jenis penelitian yang digunakan adalah rancangan penelitian Analitik observasional dengan studi cross sectional, yaitu mempelajari hubungan antara faktor resiko (jenis makanan dan minuman serta frekuensi mengonsumsinya) dan efek (ECC dan Non ECC) dengan melakukan pengumpulan data sekaligus pada satu saat (point time approach). Populasi dari penelitian adalah anak yang berusia 2-3 tahun beserta Ibunya di 3 Posyandu wilayah kerja puskesmas Tanah Garam yang berjumlah 91 orang. Teknik sampling yang digunakan adalah Purposive Sampling, yang didasarkan pada suatu pertimbangan tertentu yang dibuat oleh peneliti sendiri, berdasarkan ciri atau sifat-sifat populasi yang sudah diketahui sebelumnya melalui studi pendahuluan (Notoatmodjo, 2002 ). Pengambilan sampel dilakukan menggunakan teknik Random Sampling, dengan cara mengurutkan data anak yang memenuhi kriteria inklusi dan eksklusi, dan pengambilan sampel sesuai nomor urut ganjil ataupun genap. 
Fakultas Kedokteran Gigi Universitas Andalas Jalan Perintis Kemerdekaan No. 77 Padang, Sumatera Barat

Web: adj.fkg.unand.ac.id Email: adj@dent.unand.ac.id

$$
n=\frac{\mathrm{Z}^{2} \gamma / 2 \mathrm{P}(1-\mathrm{P}) \mathrm{N}}{d^{2}(\mathrm{~N}-1)+\mathrm{Z}^{2} \gamma / 2 \mathrm{P}(1-\mathrm{P})}
$$

Keterangan :

$$
\begin{array}{ll}
\mathrm{n} & =\text { besar sampel } \\
\mathrm{Z}^{2} \gamma / 2 & =\text { derajat kepercayaan } 95 \%, \text { yaitu } 1,96 \\
\mathrm{P} & =\text { proporsi, yaitu } 0,5 \\
\mathrm{~N} & =\text { jumlah populasi, yaitu } 91 \\
\mathrm{D} & =\text { presisi, yaitu } 0,1
\end{array}
$$

Jumlah sampel minimal yang diambil pada penelitian adalah 46 orang. Dengan penambahan proporsi $10 \%$ pada sampel penelitian sehingga jumlah sampel menjadi 50 orang.

Penentuan jumlah sampel untuk masing-masing posyandu dihitung secara proporsional dengan rumus alokasi proporsional :

$$
S=\frac{n \times S}{N}
$$

\begin{tabular}{|c|c|c|c|c|}
\hline NO & POSYANDU & $\begin{array}{l}\text { UNIT } \\
\text { POPULA } \\
\text { SI }\end{array}$ & $\begin{array}{c}\mathrm{s}=\mathrm{n} / \mathrm{NX} \\
\mathrm{S}\end{array}$ & $\begin{array}{c}\text { UNIT } \\
\text { SAMPEL }\end{array}$ \\
\hline 1 & $\begin{array}{l}\text { POSYANDU } \\
\text { BOUGENVIL } \\
1\end{array}$ & 42 & $\begin{array}{lll}42 & \text { / } 91 \quad X \\
50 & & \\
\end{array}$ & 22 \\
\hline 2 & $\begin{array}{l}\text { POSYANDU } \\
\text { BOUGENVIL } \\
2\end{array}$ & 16 & $\begin{array}{lll}16 & / 91 & X \\
50 & & \end{array}$ & 9 \\
\hline 3 & $\begin{array}{l}\text { POSYANDU } \\
\text { KASIH IBU } \\
\text { TERATAI } 12\end{array}$ & 33 & 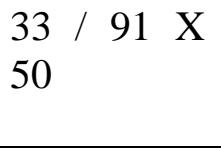 & 19 \\
\hline \multicolumn{2}{|c|}{ JUMLAH } & 91 & & 50 \\
\hline
\end{tabular}

Keterangan :

$\mathrm{s}=$ jumlah sampel tiap unit secara proporsional

$\mathrm{S}=$ jumlah seluruh sampel yang didapat

$\mathrm{n}=$ jumlah masing-masing unit populasi

$\mathrm{N}=$ jumlah populasi

\section{Pengambilan Data}

Data diperoleh dari orang tua (ibu) responden melalui kuesioner pemerikasaan gigi geligi. Setelah izin dari pihak terkait ( kampus, Dinas Kesehatan, Kepala Puskesmas Tanah Garam di Kota Solok ) peneliti meminta izin dari orangtua responden pada posyandu Bougenvil 1, posyandu Bougenvil 2, dan posyandu Kasih Ibu Teratai 12. Apabila orangtua responden memberi 
izin anaknya untuk menjadi subjek penelitian maka peneliti mempersilahkan orangtua subjek untuk menandatangani lembar persetujuan(informed consent). Setelah Informed Consent dikembalikan, dilakukan pengisian identitas anak yang mencakup nama, umur, dan jenis kelamin. Selanjutnya dilakukan pemeriksaan gigi dengan menggunakan kaca mulut dan sonde setengah lingkaran dengan bantuan penerangan dari senter mini. Kemudian masing-masing orangtua akan diwawancarai sesuai dengan daftar FFQ, lalu diisi dengan memberikan tanda cek list $(\sqrt{ })$.

\section{Pengolahan Data dan Analisa Data}

Data yang diperoleh berupa data kategorik. Dalam penelitian ini digunakan uji Chi Square. Syarat uji Chi Square adalah sel yang memiliki nilai expected kurang dari 5, maksimal 20\% dari jumlah sel. Jika syarat uji Chi Square tidak terpenuhi, maka dilakukan penggabungan sel untuk diuji ulang menggunakan uji Kolmogorov-Smirnov.

\section{HASIL DAN PEMBAHASAN}

Pada Gambar 5.1 diperoleh data responden berdasarkan tingkat kejadian Early childhood caries paling banyak yaitu dengan tingkat kejadian Early childhood caries yaitu sebesar 28 $(56 \%)$.

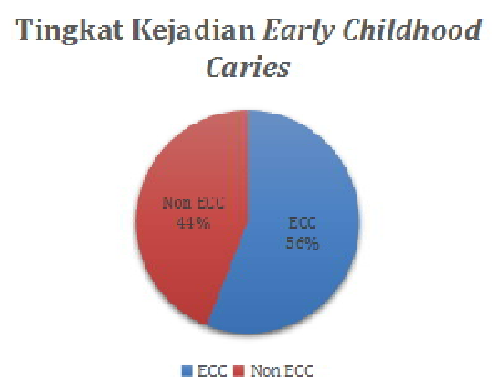


Fakultas Kedokteran Gigi Universitas Andalas Jalan Perintis Kemerdekaan No. 77 Padang, Sumatera Barat Web: adj.fkg.unand.ac.id Email: adj@dent.unand.ac.id

Analisa data jenis dan frekuensi konsumsi menggunakan distribusi frekuensi. Hasil analisis disajikan dalam Tabel 5.2.

Tabel 5.2 Distribusi

berdasarkan jenis dan frekuensi konsumsi makanan dalam 1 minggu.

\begin{tabular}{|c|c|c|c|c|c|c|c|c|c|c|}
\hline \multirow{3}{*}{$\begin{array}{c}\text { Jenis } \\
\text { Makanan }\end{array}$} & \multicolumn{9}{|c|}{ Frekuensi Pola Makan Dalam Satu Minggu } & \multirow{3}{*}{$\begin{array}{c}\text { Jumlah } \\
\%\end{array}$} \\
\hline & \multicolumn{2}{|c|}{$1-3$ kali } & \multicolumn{2}{|c|}{$\begin{array}{l}4-6 \\
\text { kali }\end{array}$} & \multicolumn{2}{|c|}{$>6$ kali } & \multicolumn{3}{|c|}{ Tidak Pernah } & \\
\hline & $\mathrm{n}$ & $\%$ & $\mathrm{n}$ & $\%$ & $\mathrm{n}$ & $\%$ & $\mathrm{n}$ & $\%$ & $\mathrm{n}$ & \\
\hline Nasi & 2 & 4 & - & - & 48 & 96 & - & - & 50 & 100 \\
\hline Jagung & 33 & $\begin{array}{l}6 \\
6\end{array}$ & 5 & 10 & 8 & 16 & - & - & 50 & 100 \\
\hline Mie instan & 35 & $\begin{array}{l}7 \\
0\end{array}$ & 3 & 6 & 2 & 4 & - & - & 50 & 100 \\
\hline Kentang & 28 & $\begin{array}{l}5 \\
6\end{array}$ & 8 & 16 & 13 & 26 & 1 & 2 & 50 & 100 \\
\hline Telur ayam & 21 & $\begin{array}{l}4 \\
2\end{array}$ & 5 & 10 & 22 & 44 & 2 & 4 & 50 & 100 \\
\hline Roti & 19 & $\begin{array}{l}3 \\
8\end{array}$ & $\begin{array}{l}1 \\
0\end{array}$ & 20 & 21 & 42 & - & - & 50 & 100 \\
\hline Kue & 17 & $\begin{array}{l}3 \\
4\end{array}$ & 9 & 18 & 23 & 46 & 1 & 2 & 50 & 100 \\
\hline Permen & 20 & $\begin{array}{l}4 \\
0\end{array}$ & 4 & 8 & 19 & 38 & 7 & 14 & 50 & 100 \\
\hline Coklat & 21 & $\begin{array}{l}4 \\
2\end{array}$ & 5 & 10 & 17 & 34 & 7 & 14 & 50 & 100 \\
\hline Snack & 24 & $\begin{array}{l}4 \\
8\end{array}$ & 7 & 14 & 18 & 36 & 1 & 2 & 50 & 100 \\
\hline
\end{tabular}

Berdasarkan Tabel 5.2 distribusi berdasarkan jenis dan frekuensi konsumsi makanan dalam 1 minggu didapatkan responden lebih banyak mengonsumsi jenis makanan kariogenik seperti roti, kue $>6$ kali seminggu, permen, coklat, snack $>3$ kali seminggu. 
Fakultas Kedokteran Gigi Universitas Andalas Jalan Perintis Kemerdekaan No. 77 Padang, Sumatera Barat Web: adj.fkg.unand.ac.id Email: adj@dent.unand.ac.id

Tabel 5.3. Distribusi berdasarkan jenis dan frekuensi konsumsi minuman dalam 1 minggu.

\begin{tabular}{|c|c|c|c|c|c|c|c|c|c|c|}
\hline \multirow{3}{*}{$\begin{array}{c}\text { Jenis } \\
\text { Minuman }\end{array}$} & \multicolumn{8}{|c|}{ Frekuensi Pola Minuman Dalam Satu Minggu } & \multicolumn{2}{|c|}{ Jumlah } \\
\hline & \multicolumn{2}{|c|}{$1-3$ kali } & \multicolumn{2}{|c|}{ 4-6 kali } & \multicolumn{2}{|c|}{$>6$ kali } & \multicolumn{2}{|c|}{ Tidak Pernah } & \multirow[b]{2}{*}{$\mathrm{n}$} & \multirow[b]{2}{*}{$\%$} \\
\hline & $\mathrm{n}$ & $\%$ & $\mathrm{n}$ & $\%$ & $\mathrm{n}$ & $\%$ & $\mathrm{n}$ & $\%$ & & \\
\hline Air putih & - & - & - & - & 50 & 100 & - & - & 50 & 100 \\
\hline $\begin{array}{l}\text { Teh tanpa } \\
\text { gula+gelas }\end{array}$ & 1 & 2 & 2 & 4 & 21 & 42 & 26 & 52 & 50 & 100 \\
\hline $\begin{array}{l}\text { Susu tanpa } \\
\text { gula+gelas }\end{array}$ & 6 & 12 & 5 & 10 & 3 & 6 & 36 & 73 & 50 & 100 \\
\hline $\begin{array}{l}\text { Jus tanpa } \\
\text { gula+gelas }\end{array}$ & 1 & 2 & 6 & 12 & 3 & 6 & 40 & 80 & 50 & 100 \\
\hline $\begin{array}{l}\text { Susu } \\
\text { gula+botol }\end{array}$ & 2 & 4 & - & - & 16 & 32 & 32 & 64 & 50 & 100 \\
\hline $\begin{array}{l}\text { Teh+gula+bot } \\
\text { ol }\end{array}$ & 18 & 36 & 2 & 4 & 7 & 14 & 23 & 46 & 50 & 100 \\
\hline $\begin{array}{l}\text { Jus+gula+bot } \\
\text { ol }\end{array}$ & 25 & 50 & 3 & 6 & - & - & 22 & 44 & 50 & 100 \\
\hline Es krim & 39 & 78 & 6 & 12 & 4 & 8 & 1 & 2 & 50 & 100 \\
\hline
\end{tabular}

Berdasarkan Tabel 5.3 distribusi responden berdasarkan jenis dan frekuensi konsumsi minuman dalam 1 minggu diketahui responden lebih memilih jenis minuman kariogenik seperti jus+gula+botol, teh+gula+botol, es krim 1-3 kali dalam seminggu, dan susu+gula+botol >6 kali seminggu.

Analisis data pola makan menggunakan distribusi frekuensi. Hasil analisis disajikan dalam gambar.

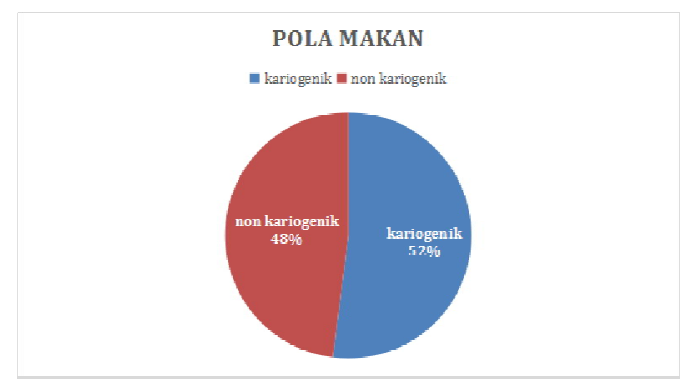

Berdasarkan Gambar 5.2 distribusi responden berdasarkan pola makan terdapat lebih banyak responden dengan pola makan kariogenik.

Hasil analisa distribusi hubungan jenis kelamin dengan tingkat kejadian Early Childhood Caries disajikan dalam Tabel 5.3 
ANDALAS DENTAL JOURNAL

Fakultas Kedokteran Gigi Universitas Andalas

Jalan Perintis Kemerdekaan No. 77 Padang, Sumatera Barat

Web: adj.fkg.unand.ac.id Email: adj@dent.unand.ac.id

Tabel 5.3 Distribusi Hubungan Jenis Kelamin dengan Tingkat Kejadian Early

Childhood Caries.

\begin{tabular}{ccccccc}
\hline Jenis & \multicolumn{3}{l}{ Tingkat Kejadian } & \multicolumn{2}{l}{ Total } \\
Kelamin & \multicolumn{3}{c}{ ECC } \\
& \multicolumn{2}{c}{ ECC } & \multicolumn{2}{c}{ Non } & & \\
& & \multicolumn{2}{c}{ ECC } & & \\
& $\mathrm{n}$ & $\%$ & $\mathrm{n}$ & $\%$ & $\mathrm{n}$ & $\%$ \\
\hline Laki-laki & 1 & 73. & 6 & 26. & 23 & 100 \\
& 7 & 9 & & 1 & & \\
Perempuan & 1 & 40. & 16 & 59. & 27 & 100 \\
& 1 & 7 & & 3 & & \\
Total & 2 & 56. & 22 & 44. & 50 & 100 \\
& 8 & 0 & & 0 & & \\
\hline
\end{tabular}

Berdasarkan Tabel 5.3 jenis kelamin laki-laki lebih banyak mengalami ECC yaitu 17 (73.9\%) dan perempuan yang mengalami ECC sebanyak 11 (40.7\%).

Hasil analisa distribusi hubungan pola makan dengan tingkat kejadian Early Childhood Caries disajikan dalam Tabel 5.4.

Tabel 5.4. Tabulasi Hubungan Pola Makan dengan Tingkat Kejadian Early

\section{Childhood Caries}

\begin{tabular}{ccccccccc}
\hline Pola Makan & \multicolumn{3}{c}{ Tingkat Kejadian } & \multicolumn{2}{c}{ Total } & $P$ & $P O R$ \\
& \multicolumn{9}{c}{ ECC } & & & \\
& ECC & \multicolumn{2}{c}{ Non ECC } & & & & \\
& $\mathrm{f}$ & $\%$ & $\mathrm{f}$ & $\%$ & $\mathrm{f}$ & $\%$ & & \\
\hline kariogenik & 21 & 80.8 & 5 & 19.2 & 26 & 100 & 0.01 & 10.2 \\
Non Kariogenik & 7 & 29.2 & 17 & 70.8 & 24 & 100 & & \\
Total & 28 & 56.0 & 22 & 44.0 & 50 & 100 & & \\
\hline
\end{tabular}

Berdasarkan analisis data diketahui terdapat hubungan yang bermakna antara pola makan dengan kejadian early childhood caries dengan nilai P 0.01. Tingkat kejadian ECC lebih banyak terjadi pada pola makan kariogenik yaitu $80.8 \%$, sedangkan pada pola makan non kariogenik $29.2 \%$. Parameter kekuatan hubungan yang digunakan adalah POR, yaitu sebesar 10.2 dengan IK 95\% 2.742-37.945. Artinya, responden dengan pola makan kariogenik mempunyai kemungkinan 10.2 kali untuk mengalami ECC dibandingkan dengan pola makan nonkariogenik.

Berdasarkan hasil pemeriksaan yang dilakukan ditemukan anak dengan ECC lebih banyak dibandingkan dengan anak yang Non ECC, yaitu sebanyak 56\%. Hasil penelitian ini sejalan 
dengan penelitian yang dilakukan oleh Morita Sari dkk di Kota Surakarta pada anak umur 3-5 tahun ditemukan prevalensi ECC sebesar $60 \% .{ }^{16}$ Sutjipto dkk melaporkan prevalensi ECC di Surabaya pada kelompok anak usia 6 bulan-3 tahun adalah 59\%. ${ }^{17}$ Setiawati et al melaporkan prevalensi ECC pada anak usia 12-38 bulan di DKI Jakarta sebesar 52,7\% ${ }^{18}$.

Berdasarkan hasil tabel 5.5 anak usia 2 tahun sudah banyak yang mengalami ECC yaitu, sebanyak 50\% atau 9 responden dan begitu juga dengan anak usia 3 tahun sebanyak $59.4 \%$ atau 19 responden. Menurut asumsi peneliti hal ini bisa terjadi karena orangtua memperkenalkan makanan kariogenik terlalu dini kepada anak, dan didalam jurnal Kiswaluyo juga menjelaskan bahwa kurangnya kesadaran orangtua untuk merawat gigi sulung anak, karena gigi tersebut dianggap akan diganti oleh gigi tetap. ${ }^{19}$ Hasil penelitian dari tabel 5.5 juga menyatakan jenis kelamin laki-laki lebih banyak mengalami ECC dibandingkan jenis kelamin perempuan, yaitu sebanyak 73.9\%. Hal ini sejalan dengan penelitian Putri R. Dengah dkk yang menyatakan terdapat tingkat karies lebih tinggi pada anak laki-laki dibandingkan perempuan. ${ }^{20}$ Hasil penelitian Indry dkk menunjukan bahwa anak laki-laki memiliki rata rata DMF-T lebih tinggi dibandingkan perempuan yaitu 3,86 dengan tingkat karies kategori sedang. ${ }^{21}$

Berdasarkan hasil penelitian menunjukan bahwa sebanyak $52 \%$ responden dengan pola makan konsumsi kariogenik. Pola konsumsi kariogenik dengan presentase terbesar terdapat pada responden mengonsumsi snack >6 kali seminggu sebanyak 24 (48\%), responden mengonsumsi kue >6 kali seminggu sebanyak 23 (46\%), responden mengonsumsi roti $>6$ kali seminggu sebanyak $21(42 \%)$, responden mengonsumsi permen >6 kali seminggu sebanyak 19 (38\%), responden mengonsumsi coklat $>6$ kali seminggu sebanyak 17 (34\%). Hasil penelitian ini sejalan dengan penelitian Rizki Safira Talibo dkk yang menyatakan konsumsi makanan kariogenik dengan frekuensi lebih sering akan berpotensi lebih besar untuk mengalami karies gigi. Begzati agin dkk (2010) melakukan penelitian pada anak-anak pra sekolah, dan menjelaskan pola konsumsi makanan manis terbanyak adalah snack dengan frekuensi lebih dari 2 kali sehari. ${ }^{22}$ Dalam penelitian Indry dkk bahwa pola makan anak usia 1-3 tahun dikelompokan sebagai konsumen pasif, di mana makanan yang dikonsumsi tergantung dari yang disajikan ibu. ${ }^{23}$

Berdasarkan hasil penelitian menunjukan bahwa pola makan non kariogenik sebanyak $48 \%$. Jenis makanan dengan presentase terbesar yaitu, 48 (96\%) responden mengonsumsi nasi $>6$ kali seminggu. Hal ini terjadi karena beras merupakan bahan pokok bagi sebagian besar masyarakat Indonesia.

Hasil penelitian dari tabel 5.3 menunjukan bahwa cara konsumsi responden yang masih banyak menggunakan botol dibandingkan gelas, yaitu total responden dari semua frekuensi yang 
menggunakan botol pada konsumsi susu dengan botol+gula sebanyak 18 orang, teh dengan botol+gula 27 orang, dan jus dengan botol+gula 28 orang. Hal ini sejalan dengan penelitian Ghaitsa menyatakan bahwa anak yang mengkonsumsi susu menggunakan botol tingkat keparahan terkena karies gigi lebih tinggi dibanding anak yang mengkonsumsi susu tanpa botol. Hasil penelitian Ghaitsa melaporkan bahwa Indeks karies pada anak yang mengkonsumsi susu botol tergolong dalam kategori tinggi yaitu sebesar 5.3 yang menunjukkan bahwa setiap anak yang mengkonsumsi susu botol rata-rata terdapat 5 gigi yang terkena karies. Indeks karies pada anak yang mengkonsumsi susu tanpa botol tergolong dalam kategori sedang yaitu sebesar 3.4 yang menunjukkan bahwa setiap anak rata-rata memiliki 3 gigi yang terkena karies. ${ }^{24}$

Hasil uji statistik menunjukan $p$ value $=0,01(\mathrm{p}<0,05)$, yang berarti adanya hubungan yang bermakna antara pola makan anak terhadap tingkat kejadian Early Childhood Caries. Secara umum, dari hasil penelitian terlihat anak-anak dengan pola makan kariogenik menderita ECC $56,0 \%$. Mereka cenderrung mengonsumsi roti, kue, permen, coklat, snack, dan susu gula dengan botol $>6$ kali seminggu. Berdasarkan hasil penelitian yang ada peneliti berasumsi bahwa anak yang lebih sering mengkonsumsi makanan kariogenik lebih banyak mengalami ECC dibandingkan anak yang jarang mengkonsumsi makanan nonkariogenik, hal ini menunjukan pengulangan konsumsi makanan kariogenik yang terlalu sering akan menyebabkan makanan tersebut akan lama menempel pada gigi sehingga dari waktu ke waktu akan terjadi karies pada gigi. Hal ini juga dibahas pada jurnal Riswandi dkk setiap kali seseorang mengonsumsi makanan dan minuman yang mengandung karbohidrat, maka bakteri penyebab karies di rongga mulut akan memproduksi asam dan mengakibatkan turunnya $\mathrm{pH}$ sampai di bawah 5 atau 4,5 dalam tempo 1-3 menit, sehingga terjadi demineralisasi yang berlangsung selama 20-30 menit setelah makan. ${ }^{25}$ Plak tersebut akan tetap asam untuk beberapa waktu dan untuk kembali ke pH plak normal sekitar 6-7 diperlukan waktu sekitar 30-60 menit. Penurunan $\mathrm{pH}$ berulang-ulang ini yang dalam waktu tertentu mengakibatkan terjadinya demineralisasi pada permukaan gigi yang rentan dan proses karies dimulai. ${ }^{26}$ Hadnyanawat dkk juga melakukan penelitian pada siswa sekolah dasar dan menjelaskan DMF-T tertinggi ditemukan pada responden yang gemar makan roti, permen dan coklat. $^{27}$

Berdasarkan hasil penelitian diketahui bahwa responden dengan pola makan nonkariogenik yang menderita ECC sebanyak 29.2\%. Hal ini dapat disebabkan dari faktor lain penyebab ECC yaitu, faktor morfologi gigi. Pit dan fisur pada gigi posterior sangat rentan terhadap karies karena sisa-sisa makanan mudah menumpuk di daerah tersebut terutama pit dan fisur yang dalam. Selain itu, permukaan gigi yang kasar juga dapat menyebabkan plak mudah 
melekat dan membantu perkembangan karies gigi. ${ }^{28}$

Berdasarkan hasil penelitian diketahui bahwa responden dengan pola makan kariogenik ditemukan Non ECC sebanyak 19.2\%. Hal ini dapat terjadi karena tingkat pola asuh dari orang tua dan pemeliharaan kebersihan mulut yang baik. Pola asuh orang tua sangat berpengaruh terhadap kejadian karies. Hal ini didukung oleh penelitian Morita Sari dkk, terdapat pengaruh antara pola asuh orang tua terhadap kejadian ECC di Kelurahan Purwosari Kota Surakarta. Pola asuh yang berupa frekuensi pemberian makan manis dan frekuensi pemberian susu pada anak. ${ }^{29}$

\section{SIMPULAN}

Berdasarkan hasil penelitian dan pembahasan hubungan pola makan anak terhadap tingkat kejadian Early Childhood Caries di Kelurahan Tanah Garam Kota Solok tahun 2018, dapat disimpulkan bahwa Prevalensi Early Childhood Caries di 3 (Tiga) posyandu Kelurahan Tanah Garam Kota Solok, yaitu pada posyandu Bougenvil 1, posyandu Bougenvil 2, dan posyandu Kasih Ibu Teratai 14 Maret tahun 2018 adalah 56\%. Pola makan anak balita pada populasi penelitian ini lebih banyak kariogenik (52\%) dibanding non kariogenik (48\%).

Terdapat hubungan yang bermakna antara pola makan anak dengan kejadian early childhood caries di Kelurahan Tanah Garam Kota Solok dengan $\mathrm{P}=0,01(\mathrm{P}<0,05)$.

\section{KEPUSTAKAAN}

Agusanty, S.F., I. Kandarina dan I.M.A. Gunawan. 2014. Faktor Risiko Sarapan Pagi dan Makanan Selingan terhadap Kejadian Overweight pada Remaja Sekolah Menengah Atas. Jurnal Gizi Klinik Indonesia 10(3): $139-149$.

Angela, A. 2005. Pencegahan primer pada anak yang berisiko karies tinggi. Maj. Ked. Gigi. (Dent. J.) 38(3): 130134.

Arifin, Z. 2015. Gambaran Pola Makan Anak Usia 3-5 Tahun dengan Gizi Kurang di Pondok Bersalin Tri Sakti Balong Tani Kecamatan Jabon-Sidiarjo. Midwiferia 1(1).

Begzati, A., M. Berisha dan K. Mega. 2010. Early Childhood Caries In Preschool Children Of Kosovo - a Serious Public Health Problem. BMC Public Health 10(788): 1-8.

Borutta, A., M. Wagner dan S. Kneist. 2010. Early Childhood Caries: A Multi-Factorial Disease. OHDMBSC IX(1): 32-38.

Budisuari, MA., Oktarina dan Muhmmad AM. 2010. Hubungan Pola Makan Dan Kebiasaan Menyikat Gigi Dengan Kesehatan Gigi dan Mulut (Karies) Di Indonesia. Buletin Penelitian Sistem Kesehatan. Volume 13; 83-91.

Christiono, S., R. Putranto. 2015. CARIES STATUS EARLY CHILDHOOD CARIES IN INDONESIAN CHILDREN WITH SPECIAL NEEDS : Study In SDLB Central Java.ODONTO Dental Journal. Volume 2. Nomer 2

Dinas Kesehatan Kota Solok. 2017. Laporan Tahunan 2017

Departemen Kesehatan RI. 2013. Riset Kesehatan Dasar Nasional. Jakarta: departemen Kesehatan RI.

Departemen Kesehatan RI. 2013. Riset Kesehatan Dasar Provinsi. Sumatera Barat: departemen Kesehatan RI.

Denga, P.R., N.W Mariati., Juliarti. 2015. Gambaran Tingkat Karies Berdasarkan Status Kebersihan Mulut Pada Anak Usia 12-13 Tahun Di SMP Katolik Santo Yohanis Penginjil Desa Laikit Minahasa Utara. Jurnal eGiGi(eG) volume 3 nomor 2

Fajriani Hendrastuty Handayani. 2011. Penatalaksanaan Early Childhood Caries (ECC). Jurnal Kedokteran Gigi. Volume 10. Makassar, Indonesia : Universitas Hasanuddin. 
Fatmawati, D.W.A. Hubungan Biofilm Streptococcus Mutans Terhadap Resiko Terjadinya Karies Gigi. Stomatognatic(J.K.G Unej) 8(3): 127-130.

Ghaitsa., Widodo dan R. Adhani. Perbandingan Indeks Karies Antara Anak yang Mengonsumsi Susu Botol dengan Tanpa Botol Usia 2-5 Tahun. Dentino (Jur.Ked. Gigi) 2(2): 205-210.

Hadnyanawati hestieyonini. 2002. Pengaruh Pola Jajan di Sekolah Terhadap Karies Gigi Pada Siswa Sekolah Dasar di Kabupaten Jember. Jurnal Kedokteran Gigi. Volume 9 (3): 24-27. Jakarta: Universitas Indonesia.

Indry Worotitjan, Christy N Mintjelungan, Paulina Gunawan. 2013. Pengalaman Karies Gigi Serta Pola Makan Dan Minum Pada Anak Sekolah Dasar Di Desa Kiawa Kecamatan Kawangkoan Utara. Jurnal Kedokteran Gigi volume 1. Medan, Indonesia : USU Press.

Jeffrey. 2016. Prevention and Treatment of Early Childhood Caries (ECC). Journal of Medicine and Health 1(3): 296-304.

Kidd Edwins AM, Joyston-Bechal. 1992. Dasar- dasar Karies. Jakarta

Kiswaluyo. 2010. Hubungan Karies Gigi Dengan Umur dan Jenis Kelamin Siswa Sekolah Dasar Di Wilayah Kerja Puskesmas Kaliwates Dan Puskesmas Wuluhan Kabupaten Jember. Stomatognatic (J.K.G. Unej) vol. 7No. $1: 26-30$

Lombo, Aprilia., Nelly Mayulu dan Paulina N.Gunawan . 2015. Status Karies Anak Usia Prasekolah Sekolah Citra Kasih yang Mengonsumsi Susu Formula. Jurnal e-GiGi (eG). Volume 3 Nomor 1.

Mariati, N.W. 2015. Pencegahan dan Perawatan Karies Rampan. Jurnal Biomedik (JBM). 7(1): 23-28.

Mamengko, Waraney., Shirley E. S. Kawengian dan Krista V. Siagian. 2016. Gambaran konsumsi jajanan dan status karies pada anak usia 3-5 tahun di Kelurahan Rinegetan Kecamatan Tondano Barat. Jurnal e-GiGi (eG). Volume 4 Nomor 1.

Moreira, Rafael da Silvera. 2012. Epidemiology of Dental Caries in the World. Oral Health Care, Research ; 150168.

Mustika, Mirna Dara., Amy N. Carabelly dan Cholil. Insidensi Karies Gigi Pada Anak Usia Prasekolah di TK MERAH MANDIANGIN MARTAPURA periode 2012-2013. Dentino (Jur. Ked. Gigi. Vol II. No 2 : 200 - 204.

Notoatmodjo, soekidjo. 2010. Metodologi Penelitian Kesehatan. Jakarta : Rineka Cipta.

Pratiwi, A., S.N. Irasanti dan L.A Garina. 2016. Hubungan Antara Kejadian dan Keparahan Karies Gigi dengan Status Gizi pada Anak Usia Praekolah. 2(2) : 653-658.

Widayati, N. 2014. Faktor yang Berhubungan dengan Karies Gigi pada Anak Usia 4-6 Tahun. Jurnal Berkala Epidemiologi 2(2): 196-205.

Winda Sherit Unaya, Paulina Gunawan, Dinar AW. 2015. Gambaran Karies Rampan Pada Siswa Pendidikan Anak Usia Dini Di Desa Pineleng Ii Indah. Jurnal e-Gigi 3(1). Universitas Sam Ratulangi 